Bull. Fac. Agric., Cairo Univ., 70:229-245 (2019).

\title{
EVALUATION OF YIELD AND QUALITY OF SOME SUGAR BEET VARIETIES UNDER SALINITY CONDITIONS AT PORT-SAID GOVERNORATE, EGYPT
}

(Received: 29.7.2019)

\author{
By \\ Noran A. M. Bassiony and *Soha R.A. Khalil \\ Variety Maintenance Research Department and *Sugar Technology Department, SCRI, \\ Agricultural Research Center, Giza, Egypt
}

\begin{abstract}
Ten imported commercial varieties: BTS-3980, Panther, Athospoly, Oscarpoly, Clavius, Pintea, BTS-8115, Palace, pepite and Carrot, were sown under two different types of soil, saline soil $\left(11.3 \mathrm{dSm}^{-1}\right)$ and the other was non-saline soil $\left(0.8 \mathrm{dSm}^{-1}\right)$ at south Port Said Governorate, Egypt (31 ${ }^{\circ}$ $\mathrm{N})$ and $\left(32^{\circ} \mathrm{E}\right)$ during two successive seasons. Sowing date was $15 \mathrm{Sep}$. in each of the two seasons, 2016/ 2017 and 2017/ 2018. This investigatiob aim to evaluate the influence of soil salinity stress on root yield and components, b) to identify saline tolerant sugar beet varieties based on salinity tolerance indices (STI), c) study the interrelationships and overlapping among (STI) using spearman rank correlation and biplot graph method, and d) plan appropriate selection strategies for improving both root yield and salt tolerance in sugar beet crop in Egypt. The results indicated that growing sugar beet under salt stress caused reduction in root length, $(9.4$ and $9.8 \mathrm{~cm})$ root diameter $(1.2$ and 1.3 $\mathrm{cm}$ ),frish root weight (252 and the $246 \mathrm{~g}$ ) and yield, (8.24 and 8.11 ton/fed), as compared to non- salt stress in the $1^{\text {st }}$ and $2^{\text {nd }}$ season, respectively. While, salinity reduced potassium, $(0.49$ and 0.37 meq/100 g beet), Alkalinity(0.84 and 0.76) \%, number of harvested roots/fed (3.21 and 3.31 thousand and sugar yield ton/fed. (1.11 and 1.09 ton/fed.) with reductions of $\%$, and compared to non-saline one, respectively. On the contrary, the less saline soil yielded roots with low values of sucrose, extractable sugar $\%$, proline and glycine betaine $\mathrm{mg} / \mathrm{g}$. fresh weight with substantial augmentation amounted to (0.84 and 0.91), (0.69 and 0.75\%), (1.03 and 1.08) and (1.61 and 1.77) percentages in case of the saline soil in the $1^{\text {st }}$ and $2^{\text {nd }}$ season, respectively. Whereas the undesirable excess of ( $\alpha$-amino-N and sodium by meq/100g beet and sugar lost to molasses $\%$ ) as impurities was $(0.44$ and 0.43$)$ and $(0.76$ and 0.74$) \mathrm{meq} / 100 \mathrm{~g}$ beet, $(0.15$ and $0.16 \%)$ in the $1^{\text {st }}$ and $2^{\text {nd }}$ season, respectively. A large array of diversity was observed among the examined varieties. Oscarpoly, Clavius and Athospoly varieties had higher root yield and better stress tolerance indices for salinity than others, therefore can be candidate as the best selectable varieties for salinity tolerance. Meanwhile, BTS-8115 and BTS-3980 varieties had lower yield reduction under stress conditions but they were not classified as stress tolerant varieties for their low yield on the average (low mean production).
\end{abstract}

Key word: Sugar beet varieties, salinity, stress tolerance indices, Spearman rank correlation

\section{INTRODUCTION}

Salt tolerance threshold in sugar beet is $7 \mathrm{dSm}^{-1}$ where its yield reduction gradient after that point is $6 \%$. However these values largely differ depending on variety, climate, irrigation management, fertility level and agricultural management methods (Mass and Grattan, 1999). The vegetative growth of the tolerant and sensitive plants goes down under salt stress conditions (Armioum, 2002). The selection of a suitable variety that can exhibit relatively higher tolerance salt stress during early growth stages along with appropriate agricultural management can help overcoming the problem. In addition, there are osmotically active substances excess impurities (nitrogen \%, sodium $\%$ and sugar loscs, to molasses). But, more important, soluble $\mathrm{N}$ components such as amino acids and betaine which are an important osmoprotectant. Globally, beet roots quality is determined by observing these qualities with enhanced concentrations of sodium and amino $\mathrm{N}$ (Hoffmann et al., 2009). Sugar beet is one of the most salt tolerant crops, but it is less tolerant 
to salinity during germination, emergence and in the seedling stage (Aly et al., 2014). Sugar beet is highly reduced under saline soil condition due to the low genetic potential of the varieties and/or the lack of proper agricultural management process implemented under such condition (Babazade et al., 2016 and Hanin et $a l ., 2016)$. Under such condition, inappropriate climate and unfavorable environmental conditions can intensify the effect of salinity stress (Ranjbar and Anagholi 2018).

Another essential point in selecting salt tolerant varieties is their yield stability that has to be evaluated in time and place. Based on the susceptibility stress index (SSI), smaller amount of SSI is indicative of low yield variation of variety subject to stress in contrast to that subject to favorable condition and its higher stability (Fischer and Maurer, 1978). The selection of more superior varieties in regard of these indices is based on lower tolerance index (Tol) and higher mean productivity (MP) (Rosielle and Hamblin, 1981). Based on stress tolerance index (STI), the stable varieties feature higher STI values (Fernandez, 1992). Of course the necessary condition for the creation of a positive and logical relationship between Tol and MP indices is that the genetic variance should be larger in stressed than in the nonstressed environment.

Generally, when Tol index gives smaller values it is an indication of the idea that the varieties performance is closer in stressed condition to unstressed condition and/or the plant is more tolerant to stress. Therefore, the selection of the best genotype is based on the genotypes that exhibit higher performance but lower performance potential subject to stress conditions. The correlation between MP and Tol is negative in the majority of the modes. Also, selection based on MP brings about performance enhancement in both the stressed and unstressed environments. In case that the objective is performance enhancement under stress conditions, selection based on MP can be useful. It has to be noted that such a selection causes a simultaneous reduction in mean productivity and 1 . performance subject to unstressed condition. In analyzing the correlation between sugar yield and stress sensitivity and tolerance, Abbasi et al., 2013 reported that STI index, mean production index (MP) and the geometric mean index (GMP) are the most adequite indices for the identification of salt tolerant hybrid.

The main objectives of the current research were a) evaluate the influence of soil salinity stress on root yield and components, b) identify saline tolerant sugar beet varieties based on salinity tolerance indices (STI), c) study the interrelationships and overlapping among (STI) using spearman rank correlation and biplot graph method and d) plan appropriate selection strategies for improving both of root yield and salt tolerance in sugar beet crop in Egypt.

\section{MATERIALS AND METHODS}

In the present study, ten varieties namely, BTS-3980, Panther, Athospoly, Oscarpoly, Clavius, Pintea, BTS-8115, Palace, Pepite and Carrot were cultivated at the south of Port Said Governorate, Egypt $\left(31^{\circ} \mathrm{N}\right.$ and $\left.32^{\circ} \mathrm{E}\right)$ in two types of soil the distance between them was about 500 meters. The first type was saline soil $\left(11.3 \mathrm{dSm}^{-1}\right)$, at Agric. Res . Stat. and the second type was non-saline $\left(0.8 \mathrm{dSm}^{-1}\right)$ in a private farm at Port Said in 2017/2016 and $2017 / 2018$ seasons. Sowing date was exactly at 15 Sep. A randomized complete block design for randomly sown ten varieties with three replications each season was used. Plot size was $21 \mathrm{~m}^{2}$ (7 $\mathrm{m}$ long and $3 \mathrm{~m}$ width). It included 6 rows with a distance of $0.50 \mathrm{~m}$ between rows and $0.20 \mathrm{~m}$ between plants within the row. The plots were irrigated with non-saline water. Soil samples were collected before sowing from all the experimental plots for a depth of $30 \mathrm{~cm}$. Chemical analysis of the saline and non-saline soil is shown in (Table (1). Sugar beet plants were harvested on March 15 at 180 days of age.

\subsection{The following characters were studied}

Determination of free proline and glycine betaine $\mathrm{mg} / \mathrm{g}$ content in leaves: it was done in the laboratory of Sugar Crops Res. Inst., Agric. Res. Center, according to the method of Bates et al. (1973) for proline and Grieve and Grattan (1983) for glycine betaine. The samples were taken at 90 days after planting and examined as followe.

1. Plant characters: At harvest, a random sample of ten roots was taken from each plot for determining root length, root diameter, root weight/plant and the number of harvested roots /fed.(number of harvested roots $=$ root yield(ton/fed)/root weight per plant). 
Table (1): Chemical analysis of the experimental soil .

\begin{tabular}{|c|c|c|c|c|c|c|c|c|c|c|c|}
\hline \multirow[b]{2}{*}{ Soil type } & \multicolumn{4}{|c|}{ Cations (mel.equ./L) } & \multicolumn{4}{|c|}{ Anions (mel.equ./L) } & \multirow[b]{2}{*}{$\mathbf{P}$} & \multirow[b]{2}{*}{$\begin{array}{l}E C \\
(\mathrm{ds} / \mathrm{m})\end{array}$} & \multirow[b]{2}{*}{$\begin{array}{l}\text { pH } \\
1: 2.5\end{array}$} \\
\hline & $\mathbf{K}^{+}$ & $\mathrm{Na}^{+}$ & $\mathbf{M g}^{++}$ & $\mathbf{C a}^{++}$ & $\mathrm{So}_{4}{ }^{-}$ & $\mathrm{Cl}^{-}$ & $\mathrm{HCO}_{3}{ }^{-}$ & $\mathrm{Co3}$ & & & \\
\hline Saline & 1.5 & 73.00 & 25.5 & 30.00 & 11.3 & 114.5 & 4.2 & - & 40.7 & 11.3 & 8.00 \\
\hline Non-Saline & 0.3 & 4.61 & 1.28 & 2.45 & 3.62 & 3.13 & 1.89 & - & 24.0 & 0.8 & 7.6 \\
\hline \multicolumn{12}{|c|}{ Macro and micro elements concentration (mel.g/kg soil) } \\
\hline \multirow{2}{*}{ Saline } & $\mathbf{N}$ & \multicolumn{2}{|c|}{$\mathbf{K}$} & $\mathbf{P}$ & \multicolumn{2}{|c|}{$\mathbf{C u}$} & \multicolumn{2}{|c|}{$\mathbf{F e}$} & \multicolumn{2}{|c|}{ Mn } & $\mathbf{Z n}$ \\
\hline & 160.0 & \multicolumn{2}{|c|}{390.6} & 0.95 & \multicolumn{2}{|c|}{5.64} & \multicolumn{2}{|l|}{6.37} & \multicolumn{2}{|c|}{2.25} & 0.06 \\
\hline Non-Saline & 39.0 & \multicolumn{2}{|c|}{123.0} & 19.91 & \multicolumn{2}{|c|}{0.61} & \multicolumn{2}{|c|}{4.12} & \multicolumn{2}{|c|}{0.59} & 0.61 \\
\hline
\end{tabular}

2. Quality traits: Qualitative analysis was done on fresh samples of sugar beet roots at Laboratory of El-Dakhlia Sugar Factory, Egypt.

3. Sucrose percentage (Pol \%) was determined in fresh macerated root according to the method of Le-Docte (1927).

4.Impurities: sodium, potassium and $\alpha$-aminonitrogen concentrations were estimated as meq $100 \mathrm{~g}$ beet and alkalinity coefficient \%: Sodium and potassium were determined in the digested solution using flamephotometry according to the method described by Brown and Lilliand (1964). $\alpha$-amino-N was determined using Hydrogenation method according to Carruthers et al. (1962) and then alkalinity coefficient (ALC) was calculated according to Ruiz-Holst et al. (2003) as follows: (ALC) \% = $(\mathrm{K}+\mathrm{Na}) /(\alpha$-amino-N $)$.

5. Purity $\%=$ Sucrose- $0.029-0.343(\mathrm{Na}+\mathrm{K})-$ 0.0939xN (Cooke and Scott 1993).

6. Sugar loss in molasses (SLM) was calculated according to Cooke and Scott (1993) as hollow: $\mathbf{S L M}=0.14(\mathrm{Na}+\mathrm{K})+0.25(\alpha$ amino N) +0.50 .

7. Extractable sugar $\%=$ Sucrose $\%$ - SLM0.6 (Dexter et al. 1967).

8.Yield: at harvest, all plants were taken from each plot for measuring root yield by weight /fed.

9. Sugar yield/fed $=$ Root yield $/$ fed $\times$ Sugar extractable (Recovery \%).

2.2. Statistical analysis: Data were subjected to individual analysis of variance of randomized complete block design and combined analysis over two soil types (Saline and non-Saline) for each season according to (Steel et al. 1997). As a routine statistical step, Levene test (1960) was run to confirm the heterogeneity of individual error terms. Least significant differences among the proper items were calculated at 0.05 probability level. For each variety; twelve stress tolerance indices were calculated based on average root yield under normal $\left(\mathrm{Y}_{\mathrm{n}}\right)$ and stress
$\left(\mathrm{Y}_{\mathrm{s}}\right)$ soil over the two seasons. The names, equations and references of the stress tolerance indices are shown in Table (2). To give an overall picture emerges the interrelationships and overlapping among the twelve stress tolerance indices, Spearsman rank correlation coefficients between all pairs of these indices were calculated. Principal component (PC) analysis was also run for grouping the similar/dissimilar stress tolerance indices. For better visualization, the first two principal components ( $\mathrm{PC} 1$ and $\mathrm{PC} 2$ ) were graphically plotted against each other using biplot graph (Yan and Rajacan, 2002).

\section{RESULTS AND DISCUSSION \\ 3.1.Salinity effect}

The results illustrated in Tables (3 to 6) show that the effect of soil salinity on some associated biochemical characters, yield and quality traits, were statistically significant at $1 \%$ and 5\% levels. Data in Table (3) suggested that reductions by $(9.4$ and $9.8 \mathrm{~cm})$ and $(1.2$ and 1.3 $\mathrm{cm})$ were evidenced in sugar beet root length and root diameter subject to salt stress in the first and second season, respectively. This could be due to the reduction in leaf area under salt stress condition and also inverse effect of salinity on photosynthesis. Another reason might be the reduction in uptake and utilization of mineral nutrients by plants under salt stress. On the contrary, the less saline soil yielded roots with minimized proline and glycine betaine (mg/g. fresh weight) with substantial augmentation amounted to $(1.03$ and $1.08 \mathrm{mg} / \mathrm{g})$ and $(1.61$ and $1.77 \mathrm{mg} / \mathrm{g})$ in the case of the more saline type in the first and second seasons, respectively. The reason may be that some of these amino-N compounds and presumably glycine betaine and proline found as impurities in the storage roots of stressed plants, result from osmotic adjustment as suggested by Brown et al., (1987). 
Table (2): The name, equation and reference of 12 saline tolerance indices.

\begin{tabular}{|c|c|c|c|}
\hline No. & Index name & Formula & Reference \\
\hline \multicolumn{4}{|c|}{ The high values of these indices indicated to saline stress tolerance } \\
\hline 1 & Mean Productivity (MP) & $\left(\mathrm{Y}_{\mathrm{n}}+\mathrm{Y}_{\mathrm{s}}\right) / 2$ & (Rosielle and Hamblin, 1981) \\
\hline 2 & Harmonic Mean (HM) & $\left(2 * Y_{n} * Y_{s}\right) /\left(Y_{n}+Y_{s}\right)$ & (Jafari et al., 2009) \\
\hline 3 & $\begin{array}{l}\text { Geometric Mean Productivity } \\
\text { (GMP) }\end{array}$ & $\left(\mathrm{Y}_{\mathrm{n}} * \mathrm{Y}_{\mathrm{s}}\right)^{0.5}$ & (Fernandez, 1992) \\
\hline 4 & Stress Tolerance Index (STI) & $\left(\mathrm{Y}_{\mathrm{n}} \times \mathrm{Y}_{\mathrm{s}}\right) /\left(\bar{Y}_{\mathrm{n}}\right)^{2}$ & (Fernandez, 1992) \\
\hline 5 & Yield Index (YI) & $\mathrm{Y}_{\mathrm{s}} / \bar{Y}_{\mathrm{s}}$ & (Gavuzzi et al., 1997) \\
\hline 6 & Yield Stability Index (YSI) & $\mathrm{Y}_{\mathrm{s}} / \mathrm{Y}_{\mathrm{p}}$ & (Bouslama and chapaugh,1984) \\
\hline 7 & $\begin{array}{l}\text { Modified Stress Tolerance Index } \\
\text { (MSTI) }\end{array}$ & $(\mathrm{YI})^{2} * \mathrm{STI}$ & (Farshadfar and Sutka, 2002) \\
\hline \multicolumn{4}{|c|}{ The low values of these indices indicated to saline stress tolerance } \\
\hline 8 & Tolerance Index (TOL) & $\mathrm{Y}_{\mathrm{n}}-\mathrm{Y}_{\mathrm{s}}$ & (Rosielle and Hamblin, 1981) \\
\hline 9 & $\begin{array}{l}\text { Stress Susceptibility Percentage } \\
\text { Index (SSPI) }\end{array}$ & $\mathrm{Tol}^{*} 100 /\left(2 * \bar{Y}_{\mathrm{n}}\right)$ & (Moosavi et al., 2008) \\
\hline 10 & Stress Susceptibility Index (SSI) & {$\left[1-\left(\mathrm{Y}_{\mathrm{s}} / \mathrm{Y}_{\mathrm{n}}\right)\right] /\left[1-\left(\bar{Y}_{\mathrm{s}} / \bar{Y}_{\mathrm{n}}\right)\right]$} & (Fisher and Maurer, 1978) \\
\hline 11 & Reduction (Red. \%) & $\left(\mathrm{Y}_{\mathrm{n}}-\mathrm{Y}_{\mathrm{s}}\right) * 100 / \mathrm{Y}_{\mathrm{n}}$ & \\
\hline 12 & Coefficient of variation (CV) & SD/Mean of $Y_{n}$ and $Y_{s}$ & (Darwish et al.,2017) \\
\hline
\end{tabular}

$\mathrm{Y}_{\mathrm{n}}$ and $\mathrm{Y}_{\mathrm{s}}$ indicate to average root yield of each genotype under normal and stress conditions.- $\bar{Y}_{\mathrm{n}}$ and $\bar{Y}_{\mathrm{s}}$ indicate to average root yield overall genotypes under normal and stress conditions.

Data in Table (4) revealed that saline soil yielded roots with excessive sucrose $\%$ by $(0.84$ and $0.91 \%$ ) in the first and second seasons, respectively, as compared to the non-saline one. Whereas, the undesirable excess in impurities represented in $\mathrm{N}$ and $\mathrm{Na}$ were $(0.44$ and 0.43 meq $/ 100 \mathrm{~g}$ roots) and $(0.76$ and $0.74 \mathrm{meq} / 100 \mathrm{~g}$ roots) but at the same time the soil salinity diminished potassium meq/100 $\mathrm{g}$ roots by $(0.49$ and $0.37 \mathrm{meq} / 100 \mathrm{~g}$ roots) in the first and second seasons, respectively. These results are in accordance with those of Dadkhah, (2005) who mentioned that moderate levels of salt stress $(150$ and $250 \mathrm{mM})$ increased the root sucrose content of smaller size of cells because small cells are more efficient at accumulating sucrose per volume and weight unit than larger cells. Another reason might be due to the inhibition of soluble acid invertase activity under moderate salt concentration. Khafagi and El-Lawendy, (1996) reported that the stimulation of sucrose accumulation in sugar beet roots under saline conditions was probably controlled to a certain extent by the inhibition of acid invertase activity. In this regard , Hoffmann et al.,(2009) reported that salinity increased unwanted sugars such as raffinose, glucose and fructose in storage root, concluded that the actual potential of extractable and sugar yield per unit area is the most economically important index in sugar beet production. Although moderate salt stress increased root sucrose content, the root yield was reduced by salinity. Salinity drastically decreased sugar content per plant due to its inverse effect on root yield. Therefore, in saline lands, plant density per unit area should be considered.

Data in Table (5) showed that soil salinity increased extractable sugar, sugar lost to molasses and alkalinity\% to about (0.69 and $0.75 \%),(0.15$ and $0.16 \%)$ and $(0.84$ and $0.76 \%$ ) in the first and second seasons, respectively, as compared to the control (nonsaline soil).

Data in Table (6) indicated that salt stress decreased the mean values of No. of harvested roots, root weight, root yield and sugar yield by (3.21 and 3.31 thousand plant/fed), (252 and $246 \mathrm{~g}),(8.24$ and $8.11 \mathrm{ton} / \mathrm{fed})$ and (1.11 and 1.09 ton/fed) in the first and second seasons, respectively. These data are in the same trend with those be assured by Hoffmann et al., 2009 who concluded that the actual potential of extractable and sugar yield per unit area is the most economically important index in sugar beet production. Although moderate salt stress increased root sucrose content, the root yield was reduced by salinity, salinity drastically decreased sugar content per plant due to its inverse effect on root yield. Therefore, in saline lands, plant density per unit area should be considered. 
Table (3): Combined analysis over to types of soil at first, 2016/2017 and second, 2017/2018 season for root length $(\mathrm{cm})$, root diameter, $(\mathrm{cm})$, proline $(\mathrm{mg} / \mathrm{g}$ fresh root) and glycine betaine $(\mathrm{mg} / \mathrm{g}$ fresh root) as affected by soil salinity and varieties.

\begin{tabular}{|c|c|c|c|c|c|c|c|c|c|c|c|c|}
\hline \multirow{3}{*}{$\begin{array}{c}\text { Varieties } \\
\text { (V) }\end{array}$} & \multicolumn{3}{|c|}{$\begin{array}{l}\text { Root length } \\
\text { (cm) }\end{array}$} & \multicolumn{3}{|c|}{$\begin{array}{l}\text { Root diameter } \\
(\mathbf{c m})\end{array}$} & \multicolumn{3}{|c|}{$\begin{array}{c}\text { Proline } \\
(\mathrm{mg} / \mathrm{g} \text { fresh root) }\end{array}$} & \multicolumn{3}{|c|}{$\begin{array}{l}\text { Glycine betaine } \\
\text { (mg/g fresh root) }\end{array}$} \\
\hline & \multicolumn{2}{|c|}{ Soil type (S) } & \multirow[b]{2}{*}{ Mean } & \multicolumn{2}{|c|}{ Soil type (S) } & \multirow[b]{2}{*}{ Mean } & \multicolumn{2}{|c|}{ Soil type (S) } & \multirow[b]{2}{*}{ Mean } & \multicolumn{2}{|c|}{ Soil type (S) } & \multirow[b]{2}{*}{ Mean } \\
\hline & Saline & $\begin{array}{c}\text { Non } \\
\text { saline }\end{array}$ & & Saline & $\begin{array}{c}\text { Non } \\
\text { saline }\end{array}$ & & Saline & $\begin{array}{c}\text { Non } \\
\text { saline }\end{array}$ & & Saline & $\begin{array}{c}\text { Non } \\
\text { saline }\end{array}$ & \\
\hline \multicolumn{13}{|c|}{$2016 / 2017$} \\
\hline 1.BTS-3980 & 17.0 & 27.8 & 22.4 & 9.7 & 11.0 & 10.4 & 2.64 & 2.16 & 1.64 & 1.765 & 0.080 & 0.970 \\
\hline 2.Panther & 21.4 & 30.4 & 25.9 & 11.8 & 12.9 & 11.9 & 1.40 & 2.11 & 1.61 & 1.853 & 0.088 & 1.656 \\
\hline 3.Athospoly & 23.0 & 31.5 & 27.2 & 12.4 & 13.5 & 12.6 & 3.97 & 4.40 & 3.28 & 3.185 & 0.127 & 0.761 \\
\hline 4.Oscarpoly & 25.4 & 32.9 & 29.2 & 12.5 & 13.6 & 13.2 & 2.20 & 1.85 & 1.43 & 1.445 & 0.076 & 0.869 \\
\hline 5.Clavius & 24.1 & 31.7 & 27.9 & 12.4 & 13.7 & 12.8 & 2.20 & 2.04 & 1.59 & 1.647 & 0.092 & 1.274 \\
\hline 6.Pinta & 19.5 & 29.2 & 24.3 & 10.6 & 11.4 & 10.9 & 3.22 & 2.94 & 2.20 & 2.446 & 0.102 & 0.940 \\
\hline 7.BTS-8115 & 16.7 & 27.6 & 22.2 & 9.6 & 10.9 & 10.3 & 1.56 & 2.02 & 1.52 & 1.802 & 0.078 & 0.847 \\
\hline 8.Palace & 17.3 & 27.9 & 22.6 & 9.7 & 11.4 & 10.7 & 1.57 & 2.02 & 1.55 & 1.614 & 0.081 & 0.702 \\
\hline 9.Pepite & 21.6 & 30.4 & 26.0 & 11.8 & 13.0 & 12.3 & 1.48 & 2.00 & 1.57 & 1.326 & 0.078 & 0.801 \\
\hline 10.Carrot & 20.1 & 30.2 & 25.1 & 10.9 & 11.8 & 11.3 & 1.60 & 1.14 & 0.90 & 1.508 & 0.094 & 0.970 \\
\hline Mean & 20.6 & 29.9 & & 11.1 & 12.3 & & 2.18 & 1.15 & & 1.765 & 0.090 & \\
\hline F -test (S) & \multicolumn{3}{|c|}{$* *$} & \multicolumn{3}{|c|}{$* *$} & \multicolumn{3}{|c|}{$* *$} & \multicolumn{3}{|c|}{$* *$} \\
\hline \multicolumn{13}{|l|}{ LSD at $5 \%$} \\
\hline$(\mathrm{V})$ & \multicolumn{3}{|c|}{1.3} & \multicolumn{3}{|c|}{0.728} & \multicolumn{3}{|c|}{0.463} & \multicolumn{3}{|c|}{0.140} \\
\hline $\mathbf{S} \times \mathbf{V}$ & \multicolumn{3}{|c|}{ NS } & \multicolumn{3}{|c|}{ NS } & & 0.655 & & & 0.198 & \\
\hline & & & & & 201 & 2018 & & & & & & \\
\hline 1. BTS-3980 & 17.5 & 27.8 & 22.6 & 9.9 & 11.0 & 10.4 & 1.35 & 1.12 & 1.99 & 1.75 & 0.08 & 0.64 \\
\hline 2. Panther & 21.1 & 30.4 & 25.8 & 11.6 & 12.3 & 12.4 & 0.80 & 1.12 & 1.10 & 1.21 & 0.07 & 1.71 \\
\hline 3. Athospoly & 22.6 & 31.6 & 27.1 & 11.9 & 13.3 & 13.0 & 1.95 & 2.16 & 2.96 & 3.29 & 0.13 & 0.87 \\
\hline 4. Oscarpoly & 24.8 & 32.3 & 28.5 & 12.2 & 14.2 & 13.1 & 1.19 & 1.02 & 1.69 & 1.65 & 0.08 & 0.87 \\
\hline 5. Clavius & 23.6 & 31.7 & 27.6 & 12.0 & 13.5 & 13.1 & 1.21 & 1.14 & 1.70 & 1.66 & 0.09 & 1.15 \\
\hline 6. Pinta & 19.2 & 30.2 & 24.7 & 10.4 & 11.4 & 11.0 & 1.61 & 1.47 & 2.41 & 2.21 & 0.09 & 0.67 \\
\hline 7. BTS-8115 & 16.7 & 28.2 & 22.5 & 9.6 & 10.9 & 10.3 & 0.82 & 1.03 & 1.19 & 1.28 & 0.06 & 0.70 \\
\hline 8. Palace & 18.1 & 29.2 & 23.6 & 10.1 & 11.3 & 10.6 & 0.83 & 1.09 & 1.20 & 1.34 & 0.06 & 0.58 \\
\hline 9. Pepite & 21.4 & 31.5 & 26.4 & 11.7 & 12.8 & 12.4 & 0.83 & 1.14 & 1.16 & 1.10 & 0.06 & 0.74 \\
\hline 10. Carrot & 19.8 & 30.4 & 25.1 & 10.8 & 11.8 & 11.3 & 0.93 & 0.66 & 1.26 & 1.38 & 0.09 & 0.64 \\
\hline Mean & 20.5 & 30.3 & & 11.0 & 12.3 & & 2.27 & 1.19 & & 1.75 & 0.08 & \\
\hline F -test (S) & & $* *$ & & & $* *$ & & & $* *$ & & & $* *$ & \\
\hline LSD at $5 \%$ & & & & & & & & & & & & \\
\hline$(\mathrm{V})$ & & 1.8 & & & 0.814 & & & 0.331 & & & 0.243 & \\
\hline $\mathbf{S} \times \mathbf{V}$ & & NS & & & NS & & & 0.468 & & & 0.343 & \\
\hline
\end{tabular}

* Level of significance at $5 \%$, **level of significance at $1 \%$

\subsection{Effect of varieties}

Data in Table (3) demonstrated that among of the studied varieties, very evident differences were scored in terms of root length, root diameter. Therefore, the highest values were obtained from Oscarpoly variety with a 
significant differences amounting of (7 and 6 $\mathrm{cm})$ and $(2.8$ and $2.9 \mathrm{~cm})$ from BTS-8115 variety which was the least in the ranking. Athospoly variety showed $(2.38$ and $1.86 \mathrm{mg} / \mathrm{g}$ fresh weight) higher value of proline $\mathrm{mg} / \mathrm{g}$ fresh weight than that recorded by Carrot and Panther in the first and second seasons, respectively. Meanwhile, Panther variety surpassed Palace which ranked last for glycine betaine with difference of ( 0.96 and $1.13 \mathrm{mg} / \mathrm{g}$ fresh weight) in the first and second seasons, respectively. In this regard, Hoffmann et al., (2009) reported that increased osmotically active substances such as proline and glycine betaine $\mathrm{mg} / \mathrm{g}$ fresh weight is a reflection of the ability of cultivars to salinity tolerance.

Data in Table (4) suggested that in regard to sucrose $\%, \alpha$-amino-N, $\mathrm{Na}$ and $\mathrm{K}$ by meq $/ 100 \mathrm{~g}$ beet the result was reversed. Whereas, BTS8115 variety surpassed the following ones with the largest declines evaluated by (3.88 and $4.1 \%$ $\mathrm{meq} / 100 \mathrm{~g}$ beet $),(0.3$ and $0.26 \mathrm{meq} / 100 \mathrm{~g}$ beet $)$, $(0.43$ and $0.35 \mathrm{meq} / 100 \mathrm{~g}$ beet $)$ and $(1.32$ and $1.15 \mathrm{meq} / 100 \mathrm{~g}$ beet) from Oscarpoly variety in the first and second seasons, respectively.

Data in Table (5) revealed that the ten tested sugar beet varieties significantly differed in extractable sugar and sugar lost to molasses which probably referred to their gene make-up. Sugar beet variety BTS-8115 had ( 0.27 and 0.32 $\%)$ and (3.83 and $3.55 \%)$ higher values compared with Oscarpoly in the first and second seasons, respectively. But, purity $\%$ of Panther exceeded that of Oscarpoly variety by (1.18 and $2.09 \%$ ) in the first and second seasons, respectively. Besides, significant differences were detected among varieties in alkalinity in the first season only.

Data in Table (6) showed that the ten examined varieties significantly differed in no. of harvested roots, root weight, root yield and sugar yield. Oscarpoly variety achieved the highest values of root weight and yield by ( 258 and 261g) and (4.02 and 4.69 ton/fed) from BTS-8115 while Panther had $(0.43$ and 0.27 ton/fed) higher sugar yield value than Oscarpoly and BTS-3980 variety in the first and second seasons, respectively. The significant varietal difference for no. of harvested roots (thousand root/fed) was scored in the first season only.

\subsection{Effect of interaction}

The interaction of variety $\times$ salt stress significantly influenced root weight and root yield /fed), when the diminishing of its values as a result of salinity varied from (305 and $169 \mathrm{~g})$, (373 and $178 \mathrm{~g}$ ), (9.29 and $6.39 \mathrm{ton} / \mathrm{fed}$ ) and (9.17 and 6.71 ton.fed) for Oscarpoly and BTS8115 in the first and second seasons, respectively, when the $\mathrm{Na}$ as meq/100 $\mathrm{g}$ beet observed reductions from BTS-8115 in saline comparison to Oscarpoly in non- saline soil were (1.14 and 1.08) meq/100 g beet in the first and second seasons, respectively. So, the studied varieties as well showed different reactions to salt stress. Based thereon, there are acceptable varieties to be introduced to the farmers for cultivation under salinity conditions. The obtained results are in harmony with those of Nasab et al., (2011) who indicated that root fresh weight differed with different cultivars under salinity stress conditions.

\subsection{Stress tolerance indices calculated}

Results in Table (7) present the root yield of the tested varieties under non salt (Yn) and salt stress (Ys) conditions as well as the estimates of salt tolerance indices and their respective ranks. If the varieties were screened based on stress tolerance indices subject to saline and non-saline conditions, the Oscarpoly sugar beet variety can be selected amongst the varieties that possessed high root yield on average. This variety which was located in the right hand upper quarter (Fig. 1) featured high mean productivity (MP), harmonic mean (HM), geometric mean productivity (GMP), stress tolerance index(STI), yield index(YI), yield stability index (YSI), and modified stress tolerance index (MSTI) with values amounting of $21.97,21.00,21.47,0.82,1.116,0.653$ and 1.02 , respectively. Moreover, this variety possessed low values of tolerance index (TOL), stress sensitivity percentage index (SSPI), reduction index (Red), stress sensitivity index (SSI), and coefficient of variation (CV \%) registered 9.23, 19.45, 34.73, 1.008 and 29.71, respectively. Oscarpoly sugar beet variety could be recommended to be more tolerant to salt stress. The closest varieties to this region were Athospoly and Clavius with values of (20.93 and 21.11), (19.90 and 20.04), (20.41 and 20.57), (0.74 and 0.75), (1.048 and 1.053), (0.673 and 0.634), (0.81 and 0.71) for MP, HM, GMP, STI, YI, YSI and MSTI, respectively, but with values of (9.27 and 9.47), and (19.53 and 19.96), (36.27 and 36.65), (1.052 and 1.063) and (31.33 and 31.73) for TOL, SSPI, Red, SSI and CV, respectively. Carrot, Pintea and Palace varieties had lower differences between stress and 
Table (4): Combined analysis over to types of soil at first, 2016/2017 and second, 2017/2018 season for sucrose $\%, \alpha$-amino $-\mathrm{N}$, sodium and potassium (meq/100g beet) as affected by soil salinity and varieties.

\begin{tabular}{|c|c|c|c|c|c|c|c|c|c|c|c|c|}
\hline \multirow{3}{*}{$\begin{array}{c}\text { Varieties } \\
\text { (V) }\end{array}$} & \multicolumn{3}{|c|}{$\begin{array}{c}\text { Sucrose } \\
\%\end{array}$} & \multicolumn{3}{|c|}{$\begin{array}{c}\alpha \text {-amino }-\mathrm{N} \\
\text { meq/100g beet }\end{array}$} & \multicolumn{3}{|c|}{$\begin{array}{c}\text { Sodium(Na) } \\
\text { meq/100g beet }\end{array}$} & \multicolumn{3}{|c|}{$\begin{array}{l}\text { Potassium (k) } \\
\text { meq/100g beet }\end{array}$} \\
\hline & \multicolumn{2}{|c|}{ Soil type (S) } & \multirow[b]{2}{*}{ Mean } & \multicolumn{2}{|c|}{ Soil type (S) } & \multirow[b]{2}{*}{ Mean } & \multicolumn{2}{|c|}{ Soil type (S) } & \multirow[b]{2}{*}{ Mean } & \multicolumn{2}{|c|}{ Soil type (S) } & \multirow[t]{2}{*}{ Mean } \\
\hline & Saline & $\begin{array}{c}\text { Non } \\
\text { saline }\end{array}$ & & Saline & $\begin{array}{c}\text { Non } \\
\text { saline }\end{array}$ & & Saline & $\begin{array}{c}\text { Non } \\
\text { saline }\end{array}$ & & Saline & $\begin{array}{c}\text { Non } \\
\text { saline }\end{array}$ & \\
\hline \multicolumn{13}{|c|}{ 2016/2017 } \\
\hline 1. BTS-3980 & 19.37 & 18.30 & 18.83 & 1.99 & 1.53 & 1.76 & 2.73 & 1.86 & 2.30 & 4.15 & 4.74 & 4.45 \\
\hline 2. Panther & 19.03 & 17.91 & 18.47 & 1.86 & 1.43 & 1.65 & 2.57 & 1.84 & 2.20 & 3.76 & 4.09 & 3.93 \\
\hline 3. Athospoly & 16.97 & 16.14 & 16.55 & 1.86 & 1.47 & 1.66 & 2.50 & 1.84 & 2.17 & 3.66 & 3.95 & 3.81 \\
\hline 4. Oscarpoly & 15.13 & 15.00 & 15.07 & 1.69 & 1.30 & 1.50 & 2.23 & 1.69 & 1.96 & 3.51 & 3.62 & 3.57 \\
\hline 5. Clavius & 15.83 & 15.48 & 15.66 & 1.78 & 1.37 & 1.57 & 2.27 & 1.69 & 1.98 & 3.52 & 3.67 & 3.60 \\
\hline 6. Pinta & 19.10 & 18.01 & 18.56 & 1.95 & 1.50 & 1.73 & 2.67 & 1.85 & 2.26 & 4.00 & 4.47 & 4.24 \\
\hline 7. BTS-8115 & 19.60 & 18.75 & 19.17 & 1.99 & 1.53 & 1.76 & 2.77 & 1.86 & 2.31 & 4.36 & 5.07 & 4.72 \\
\hline 8. Palace & 19.33 & 18.17 & 18.75 & 1.95 & 1.50 & 1.73 & 2.70 & 1.85 & 2.28 & 4.07 & 4.60 & 4.34 \\
\hline 9. Pepite & 18.00 & 16.68 & 17.34 & 1.86 & 1.43 & 1.65 & 2.57 & 1.84 & 2.20 & 3.69 & 3.89 & 3.79 \\
\hline 10. Carrot & 19.10 & 17.99 & 18.55 & 1.91 & 1.43 & 1.67 & 2.63 & 1.85 & 2.24 & 3.83 & 4.21 & 4.02 \\
\hline Mean & 17.99 & 17.15 & & 1.88 & 1.44 & & 2.61 & 1.85 & & 3.88 & 4.74 & \\
\hline F-test (S) & \multicolumn{3}{|c|}{$* *$} & \multicolumn{3}{|c|}{$* *$} & \multicolumn{3}{|c|}{$* *$} & \multicolumn{3}{|c|}{$* *$} \\
\hline \multicolumn{13}{|c|}{ LSD at $5 \%$ for } \\
\hline $\mathbf{V}$ & \multicolumn{3}{|c|}{0.703} & \multicolumn{3}{|c|}{0.067} & \multicolumn{3}{|c|}{0.061} & \multicolumn{3}{|c|}{0.254} \\
\hline $\mathbf{S} \times \mathbf{V}$ & \multicolumn{3}{|c|}{$\mathrm{NS}$} & \multicolumn{3}{|c|}{$\mathrm{NS}$} & & 0.086 & & & 0.360 & \\
\hline & & & & & 201 & 12018 & & & & & & \\
\hline 1.BTS-3980 & 19.33 & 18.17 & 18.75 & 1.95 & 1.50 & 1.73 & 2.80 & 1.91 & 2.36 & 4.30 & 5.00 & 4.65 \\
\hline 2.Panther & 18.03 & 17.74 & 17.89 & 1.91 & 1.47 & 1.69 & 2.63 & 1.88 & 2.26 & 3.73 & 4.04 & 3.89 \\
\hline 3.Athospoly & 16.63 & 15.83 & 16.23 & 1.86 & 1.43 & 1.65 & 2.60 & 1.85 & 2.22 & 3.63 & 3.84 & 3.74 \\
\hline 4.Oscarpoly & 15.47 & 15.00 & 15.23 & 1.65 & 1.27 & 1.46 & 2.20 & 1.66 & 1.93 & 3.34 & 3.41 & 3.37 \\
\hline 5.Clavius & 15.92 & 15.65 & 15.78 & 1.73 & 1.33 & 1.53 & 2.37 & 1.76 & 2.07 & 3.51 & 3.65 & 3.58 \\
\hline 6.Pinta & 19.07 & 18.00 & 18.53 & 1.91 & 1.47 & 1.69 & 2.70 & 1.89 & 2.30 & 4.10 & 4.91 & 4.51 \\
\hline 7.BTS-8115 & 19.77 & 18.45 & 19.11 & 1.99 & 1.53 & 1.76 & 2.80 & 1.91 & 2.36 & 4.34 & 5.05 & 4.69 \\
\hline 8.Palace & 19.10 & 18.03 & 18.57 & 1.95 & 1.50 & 1.73 & 2.70 & 1.90 & 2.30 & 4.20 & 4.96 & 4.58 \\
\hline 9.Pepite & 17.57 & 16.66 & 17.11 & 1.91 & 1.47 & 1.69 & 2.60 & 1.86 & 2.23 & 3.69 & 3.95 & 3.82 \\
\hline 10.Carrot & 19.03 & 17.93 & 18.48 & 1.91 & 1.47 & 1.69 & 2.70 & 1.88 & 2.29 & 3.99 & 4.87 & 4.43 \\
\hline Mean & 18.15 & 17.24 & & 1.88 & 1.45 & & 2.56 & 1.82 & & 4.37 & 5.00 & \\
\hline F-test (S) & & $* *$ & & & $* *$ & & & $* *$ & & & $* *$ & \\
\hline LSD at $5 \%$ fo & & & & & & & & & & & & \\
\hline $\mathbf{V}$ & & 0.724 & & & 0.073 & & & 0.096 & & & 0.503 & \\
\hline $\mathbf{S} \times \mathbf{V}$ & & NS & & & NS & & & 0.136 & & & NS & \\
\hline
\end{tabular}

* Level of significance at $5 \%$, **evel of significance at $1 \%$ 
Table (5): Combined analysis over to types of soil at first, 2016/2017 and second, 2017/2018 season for extractable sugar, sugar lost to molasses, alkalinity and purity \% as affected by soil salinity and varieties.

\begin{tabular}{|c|c|c|c|c|c|c|c|c|c|c|c|c|}
\hline \multirow{3}{*}{$\begin{array}{l}\text { Varieties } \\
\text { (V) }\end{array}$} & \multicolumn{3}{|c|}{$\begin{array}{c}\text { Extractable sugar } \\
\%\end{array}$} & \multicolumn{3}{|c|}{$\begin{array}{l}\text { Sugar lost to molasses } \\
\text { (SLM)\% }\end{array}$} & \multicolumn{3}{|c|}{$\begin{array}{l}\text { Alkalinity } \\
\%\end{array}$} & \multicolumn{3}{|c|}{$\begin{array}{c}\text { Purity } \\
\%\end{array}$} \\
\hline & \multicolumn{2}{|c|}{ Soil type (S) } & \multirow[b]{2}{*}{ Mean } & \multicolumn{2}{|c|}{ Soil type (S) } & \multirow[b]{2}{*}{ Mean } & \multicolumn{2}{|c|}{ Soil type (S) } & \multirow[b]{2}{*}{ Mean } & \multicolumn{2}{|c|}{ Soil type (S) } & \multirow[b]{2}{*}{ Mean } \\
\hline & Saline & $\begin{array}{c}\text { Non } \\
\text { saline }\end{array}$ & & Saline & $\begin{array}{c}\text { Non } \\
\text { saline }\end{array}$ & & Saline & $\begin{array}{c}\text { Non } \\
\text { saline }\end{array}$ & & Saline & $\begin{array}{c}\text { Non } \\
\text { saline }\end{array}$ & \\
\hline \multicolumn{13}{|c|}{$2016 / 2017$} \\
\hline 1 .BTS-3980 & 16.81 & 16.75 & 16.35 & 1.96 & 1.98 & 1.88 & 3.45 & 4.31 & 3.88 & 86.64 & 86.77 & 86.59 \\
\hline 2 .Panther & 16.58 & 15.57 & 16.10 & 1.85 & 1.87 & 1.77 & 3.41 & 4.13 & 3.77 & 86.32 & 87.11 & 86.69 \\
\hline 3.Athospoly & 14.54 & 14.20 & 14.20 & 1.83 & 1.84 & 1.75 & 3.31 & 3.95 & 3.63 & 85.34 & 85.68 & 85.55 \\
\hline 4.Oscarpoly & 12.81 & 13.18 & 12.82 & 1.73 & 1.69 & 1.65 & 3.40 & 4.09 & 3.74 & 85.20 & 84.61 & 85.51 \\
\hline 5.Clavius & 13.48 & 13.56 & 13.39 & 1.75 & 1.76 & 1.67 & 3.26 & 3.92 & 3.59 & 85.15 & 85.08 & 85.55 \\
\hline 6.Pinta & 16.58 & 16.54 & 16.12 & 1.92 & 1.93 & 1.84 & 3.42 & 4.21 & 3.82 & 86.73 & 86.79 & 86.65 \\
\hline 7.BTS-8115 & 17.01 & 17.17 & 16.65 & 1.99 & 2.00 & 1.92 & 3.58 & 4.52 & 4.05 & 86.85 & 86.76 & 86.76 \\
\hline 8. Palace & 16.80 & 16.55 & 16.29 & 1.94 & 1.95 & 1.86 & 3.47 & 4.30 & 3.88 & 86.62 & 86.87 & 86.55 \\
\hline 9. Pepite & 15.56 & 15.11 & 14.99 & 1.84 & 1.85 & 1.75 & 3.38 & 4.00 & 3.69 & 86.00 & 86.44 & 86.15 \\
\hline 10. Carrot & 16.62 & 16.52 & 16.15 & 1.88 & 1.91 & 1.80 & 3.40 & 4.24 & 3.82 & 86.79 & 86.99 & 86.67 \\
\hline Mean & 16.81 & 16.75 & & 1.87 & 1.71 & & 3.46 & 4.30 & & 86.16 & 86.37 & \\
\hline F-test (S) & & \multicolumn{2}{|l|}{$* *$} & \multicolumn{3}{|c|}{$* *$} & \multicolumn{3}{|c|}{$* *$} & & & \\
\hline \multicolumn{13}{|l|}{ LSD at $5 \%$} \\
\hline Varieties(V) & & \multicolumn{2}{|c|}{0.096} & \multicolumn{3}{|c|}{0.041} & \multicolumn{3}{|c|}{0.241} & \multicolumn{3}{|c|}{0.627} \\
\hline$S \times V$ & & \multicolumn{2}{|c|}{ NS } & \multicolumn{3}{|c|}{ NS } & \multicolumn{3}{|c|}{ NS } & & NS & \\
\hline & & & & & 201 & $/ 2018$ & & & & & & \\
\hline 1. BTS-3980 & 15.89 & 15.72 & 16.24 & 1.81 & 1.84 & 1.91 & 3.64 & 4.61 & 4.12 & 86.54 & 86.83 & 86.80 \\
\hline 2. Panther & 15.62 & 15.44 & 15.51 & 1.69 & 1.70 & 1.78 & 3.34 & 4.04 & 3.69 & 87.06 & 87.21 & 87.16 \\
\hline 3.Athospoly & 13.86 & 13.58 & 13.89 & 1.68 & 1.65 & 1.75 & 3.35 & 3.98 & 3.66 & 85.75 & 85.88 & 85.78 \\
\hline 4.Oscarpoly & 12.83 & 12.88 & 13.03 & 1.57 & 1.53 & 1.61 & 3.37 & 4.00 & 3.69 & 85.82 & 85.54 & 85.07 \\
\hline 5. Clavius & 13.29 & 13.46 & 13.51 & 1.59 & 1.59 & 1.67 & 3.40 & 4.07 & 3.73 & 85.94 & 85.80 & 85.44 \\
\hline 6. Pinta & 15.65 & 15.58 & 16.06 & 1.76 & 1.82 & 1.88 & 3.57 & 4.64 & 4.11 & 86.56 & 86.89 & 86.84 \\
\hline 7. BTS-8115 & 16.30 & 15.99 & 16.58 & 1.85 & 1.86 & 1.93 & 3.59 & 4.55 & 4.07 & 86.67 & 86.91 & 86.83 \\
\hline 8. Palace & 15.79 & 15.60 & 16.07 & 1.78 & 1.83 & 1.89 & 3.54 & 4.57 & 4.05 & 86.49 & 86.89 & 86.88 \\
\hline 9. Pepite & 14.41 & 14.38 & 14.75 & 1.66 & 1.68 & 1.77 & 3.30 & 3.96 & 3.63 & 86.30 & 86.44 & 86.44 \\
\hline 10. Carrot & 15.69 & 15.52 & 16.02 & 1.71 & 1.81 & 1.86 & 3.51 & 4.60 & 4.06 & 86.55 & 87.15 & 87.07 \\
\hline Mean & 15.89 & 15.72 & & 1.88 & 1.73 & & 3.41 & 4.17 & & 86.31 & 86.55 & \\
\hline F-test (S) & & $* *$ & & & $* *$ & & & $* *$ & & & $* *$ & \\
\hline LSD at $5 \%$ & & & & & & & & & & & & \\
\hline Varieties (v) & & 0.702 & & & 0.070 & & & NS & & & 0.815 & \\
\hline $\mathbf{S} \times \mathbf{V}$ & & NS & & & NS & & & NS & & & NS & \\
\hline
\end{tabular}

* Level of significance at $5 \%$, **level of significance at $1 \%$ 
Table (6): Combined analysis over to types of soil at first, 2016/2017 and second, 2017/2018 season for number of harvested roots (1000/fed), root weight (g/plant), root and sugar yield (ton/fed) as affected by soil salinity and varieties.

\begin{tabular}{|c|c|c|c|c|c|c|c|c|c|c|c|c|}
\hline \multirow{3}{*}{$\begin{array}{c}\text { Varieties } \\
(\mathbf{V})\end{array}$} & \multicolumn{3}{|c|}{$\begin{array}{c}\text { Number of harvested } \\
\text { Roots }(1000 / \text { fed })\end{array}$} & \multicolumn{3}{|c|}{$\begin{array}{c}\text { Root weight } \\
\text { (g/plant) }\end{array}$} & \multicolumn{3}{|c|}{$\begin{array}{c}\text { Root yield } \\
\text { (ton/fed) }\end{array}$} & \multicolumn{3}{|c|}{$\begin{array}{l}\text { Sugar yield } \\
\text { (ton/fed) }\end{array}$} \\
\hline & \multicolumn{2}{|c|}{ Soil type (S) } & \multirow[b]{2}{*}{ Mean } & \multicolumn{2}{|c|}{ Soil type (S) } & \multirow[b]{2}{*}{ Mean } & \multicolumn{2}{|c|}{ Soil type (S) } & \multirow[b]{2}{*}{ Mean } & \multicolumn{2}{|c|}{ Soil type (S) } & \multirow[b]{2}{*}{ Mean } \\
\hline & Saline & $\begin{array}{c}\text { Non } \\
\text { saline }\end{array}$ & & Saline & $\begin{array}{c}\text { Non } \\
\text { saline }\end{array}$ & & Saline & $\begin{array}{c}\text { Non } \\
\text { saline }\end{array}$ & & Saline & $\begin{array}{c}\text { Non } \\
\text { saline }\end{array}$ & \\
\hline \multicolumn{13}{|c|}{$2016 / 2017$} \\
\hline 1.BTS-3980 & 19.77 & 23.32 & 21.54 & 725 & 905 & 815 & 14.32 & 21.09 & 18.06 & 2.51 & 3.36 & 2.93 \\
\hline 2.Panther & 19.50 & 22.99 & 21.25 & 803 & 1083 & 943 & 15.65 & 24.80 & 20.08 & 2.54 & 3.87 & 3.21 \\
\hline 3.Athospoly & 19.36 & 21.96 & 20.66 & 848 & 1165 & 1007 & 16.42 & 25.58 & 20.85 & 2.35 & 3.54 & 2.94 \\
\hline 4.Oscarpoly & 19.19 & 22.00 & 20.60 & 915 & 1220 & 1067 & 17.55 & 26.84 & 21.73 & 2.20 & 3.37 & 2.87 \\
\hline 5. Clavius & 19.33 & 21.73 & 20.53 & 855 & 1193 & 1024 & 16.54 & 25.93 & 20.97 & 2.18 & 3.42 & 2.80 \\
\hline 6. Pinta & 19.58 & 22.99 & 21.29 & 777 & 1017 & 897 & 15.22 & 23.37 & 18.78 & 2.51 & 3.52 & 3.01 \\
\hline 7.BTS-8115 & 19.77 & 23.18 & 21.47 & 724 & 893 & 809 & 14.31 & 20.70 & 17.71 & 2.44 & 3.43 & 2.94 \\
\hline 8. Palace & 19.72 & 23.05 & 21.39 & 737 & 935 & 836 & 14.54 & 21.55 & 18.40 & 2.54 & 3.43 & 2.98 \\
\hline 9.Pepite & 19.47 & 22.97 & 21.22 & 814 & 1083 & 949 & 15.84 & 24.83 & 20.31 & 2.44 & 3.60 & 3.02 \\
\hline 10. Carrot & 19.54 & 23.10 & 21.32 & 787 & 1017 & 902 & 15.38 & 23.48 & 18.87 & 2.53 & 3.54 & 3.03 \\
\hline Mean & 19.52 & 22.74 & 21.32 & 799 & 1051 & & 15.52 & 23.63 & & 2.42 & 3.51 & \\
\hline F-test $(S)$ & \multicolumn{3}{|c|}{$* *$} & \multicolumn{3}{|c|}{$* *$} & \multicolumn{3}{|c|}{$* *$} & \multicolumn{3}{|c|}{$* *$} \\
\hline \multicolumn{13}{|l|}{ LSD at 5\% } \\
\hline $\operatorname{Varieties}(\mathbf{V})$ & \multicolumn{3}{|c|}{0.070} & \multicolumn{3}{|c|}{42.79} & \multicolumn{3}{|c|}{0.643} & \multicolumn{3}{|c|}{0.193} \\
\hline $\mathbf{S} \times \mathbf{V}$ & \multicolumn{3}{|c|}{ N.S } & \multicolumn{3}{|c|}{60.52} & & 0.910 & & & N.S & \\
\hline & & & & & 201 & $7 / 2018$ & & & & & & \\
\hline 1.BTS-3980 & 19.64 & 23.46 & 21.55 & 761 & 908 & 835 & 14.94 & 21.18 & 17.71 & 2.40 & 3.32 & 2.86 \\
\hline 2. Panther & 19.57 & 24.10 & 21.84 & 786 & 1030 & 908 & 15.36 & 24.79 & 20.22 & 2.43 & 3.83 & 3.13 \\
\hline 3.Athospoly & 19.39 & 22.32 & 20.86 & 833 & 1145 & 989 & 16.15 & 25.55 & 21.00 & 2.33 & 3.48 & 2.90 \\
\hline 4.Oscarpoly & 19.26 & 20.84 & 20.05 & 890 & 1263 & 1077 & 17.14 & 26.31 & 22.20 & 2.31 & 3.45 & 2.88 \\
\hline 5. Clavius & 19.40 & 22.21 & 20.81 & 835 & 1160 & 997 & 16.19 & 25.74 & 21.23 & 2.25 & 3.49 & 2.87 \\
\hline 6. Pinta & 19.62 & 22.82 & 21.22 & 770 & 993 & 882 & 15.10 & 22.47 & 19.29 & 2.52 & 3.64 & 3.08 \\
\hline 7.BTS-8115 & 19.77 & 23.31 & 21.54 & 727 & 905 & 816 & 14.36 & 21.07 & 17.51 & 2.46 & 3.31 & 2.88 \\
\hline 8.Palace & 19.61 & 23.21 & 21.41 & 770 & 935 & 853 & 15.09 & 21.71 & 18.04 & 2.41 & 3.37 & 2.89 \\
\hline 9. Pepite & 19.49 & 23.66 & 21.58 & 804 & 1058 & 931 & 15.67 & 24.94 & 20.33 & 2.40 & 3.57 & 2.99 \\
\hline 10. Carrot & 19.58 & 22.43 & 21.00 & 776 & 1007 & 891 & 15.19 & 22.55 & 19.43 & 2.54 & 3.64 & 3.09 \\
\hline Mean & 19.53 & 22.84 & & 795 & 1041 & & 15.58 & 23.82 & & 2.42 & 3.51 & \\
\hline F-test (S) & & $* *$ & & & $* *$ & & & $* *$ & & & $* *$ & \\
\hline LSD at $5 \%$ & & & & & & & & & & & & \\
\hline Varieties(V) & & N.S & & & 62.20 & & & 0.867 & & & 0.217 & \\
\hline$S \times V$ & & N.S & & & 87.96 & & & 1.230 & & & N.S & \\
\hline
\end{tabular}

\footnotetext{
* Level of significance at $5 \%, \quad * *$ level of significance at $1 \%$
} 
unstressed conditions (less Tol, SSPI, reduction Index, SSI and CV by (7.73, 7.76 and 6.81), $(16.29,16.35$ and 14.35), (33.58, 33.86 and $31.48),(0.974,0.982$ and 0.914$)$ and (28.54, 28.82 and 26.42, respectively) but less in STI and mean productivity together. Varieties Panther and Pepite are situated in an acceptable place in Fig. (1). These varieties can be classified as acceptable ones due to these higher Tol and reduction index by ( 9.3 and 37.50$)$ and (19.26 and 36.72, respectively).Thus, they can be subjected to supplementary experiments so as to avoid omitting the good genotypes (Anagholi et al., 2018). On the other hand, the least Tol and Red index pertained to BTS 8115 and BTS 3980 which were found having a low mean production for its low yield under unstressed conditions, so it is not useful for the salinity stress. Based on the insignificant effect of variety $\mathrm{x}$ soil type interaction on sugar yield, none of the studied varieties could be suggested in saline condition; consequently, they do not possess manufacturing advantage. Despite of their high sugar yield in non-saline condition, they are not appropriate in saline condition due to low sugar yield in salinity stress condition.

It is noted that indices of MP, HM, GMP, STI, YI and MSTI gave similar ranks for salt tolerance where the varieties Oscarpoly, Clavius and Athospoly varieties were identified as salt tolerant varieties. The aforementioned varieties had greater scores of evidences; the higher values of these indices indicate that they are more tolerant varieties. While the varieties BTS 8115 , BTS 3980 and Palace were identified as sensitive because of their low estimates of such indices. In the same context, the indices TOL and SSPI ranked the tested varieties for salt tolerance in the same order. Using these two indices, the varieties BTS 3980 and BTS 8115 were more tolerant for salinity, while Clavius and Panther verities were more sensitive compared to the others. A similar ranking pattern of tolerant/sensitive varieties was obtained by the indices of Red, SSI and CV. Accordingly, BTS 3980 and BTS 8115 were preferred for cultivation in the salt site, while Panther and Pepite were more sensitive for salinity. The similarity among indices in ranking varieties for salt tolerance may be attributed to that these indices are a function of each other as shown in Table (7). However, the three indices YSI and MSTI gave a different arrangement of varieties for their tolerance to salinity. A similar trend of results was found by Asadi et al.
(2012), Al-Ashkar and El-Kafafi (2014), Saad et al. (2014), Al Naggar et al., (2015), Hassan et al. (2015), Mohammadi (2016), Singh et al. (2015) and Ali and El-Sadek (2016).

On the other hand, the yield indices, MP, HM, GMP, STI, YI and MSTI ranked the tested varieties for salt tolerance exactly like the average root yield under the stress condition which means that these indices emphasized on information could be provided by root yield itself (Table 7).

Table (7) presents the root yield of sugar beet varieties under adequate (Yn) and salt stress (Ys) conditions as well as the estimates of salt tolerance indices and their respective ranks. If the varieties were screened based on stress tolerance indices subject to saline and non-saline conditions, the Oscarpoly variety can be selected amongst the sugar beet varieties that possessed high root yield on average. This variety which is located in the right hand upper quarter (Fig. 1) featured high mean productivity (MP), harmonic mean (HM), geometric mean productivity (GMP), stress tolerance index(STI), yield index(YI), yield stability index (YSI), and modified stress tolerance index (MSTI) with values amounting of $21.97,21.00,21.47,0.82$, $1.116,0.653$ and 1.02, respectively. Moreover, this variety possessed low values of tolerance index (TOL), stress sinsitivity percentage index (SSPI), reduction index (Red), stress sinsitivity index (SSI), and coefficient of variation (CV\%) registered 9.23, 19.45, 34.73, 1.008 and 29.71, respectively. Hence, it would be more tolerant to salt stress. The closest varieties to this region were Athospoly and Clavius with values of (20.93 and 21.11), (19.90 and 20.04), (20.41 and 20.57), (0.74 and 0.75), (1.048 and 1.053), (0.673 and 0.634), (0.81 and 0.71) for MP, HM, GMP, STI, YI, YSI and MSTI, respectively, but (9.27 and 9.47), and (19.53 and 19.96), (36.27 and 36.65), (1.052 and 1.063) and (31.33 and 31.73) for TOL, SSPI, Red, SSI and CV, respectively. Carrot, Pintea and Palace had lower differences between stress and unstressed conditions (lower Tol, SSPI, reduction Index, SSI and CV by (7.73, 7.76 and 6.81), (16.29, 16.35 and 14.35), (33.58, 33.86 and 31.48), $(0.974,0.982$ and 0.914$)$ and $(28.54,28.82$ and 26.42), respectively, but less STI and mean productivity together. Varieties Panther and Pepite are situated in an acceptable place in Fig.(1). These varieties can be classified as acceptable ones due to these higher Tol and reduction index by 9.3 and 37.50 and 19.26 and 


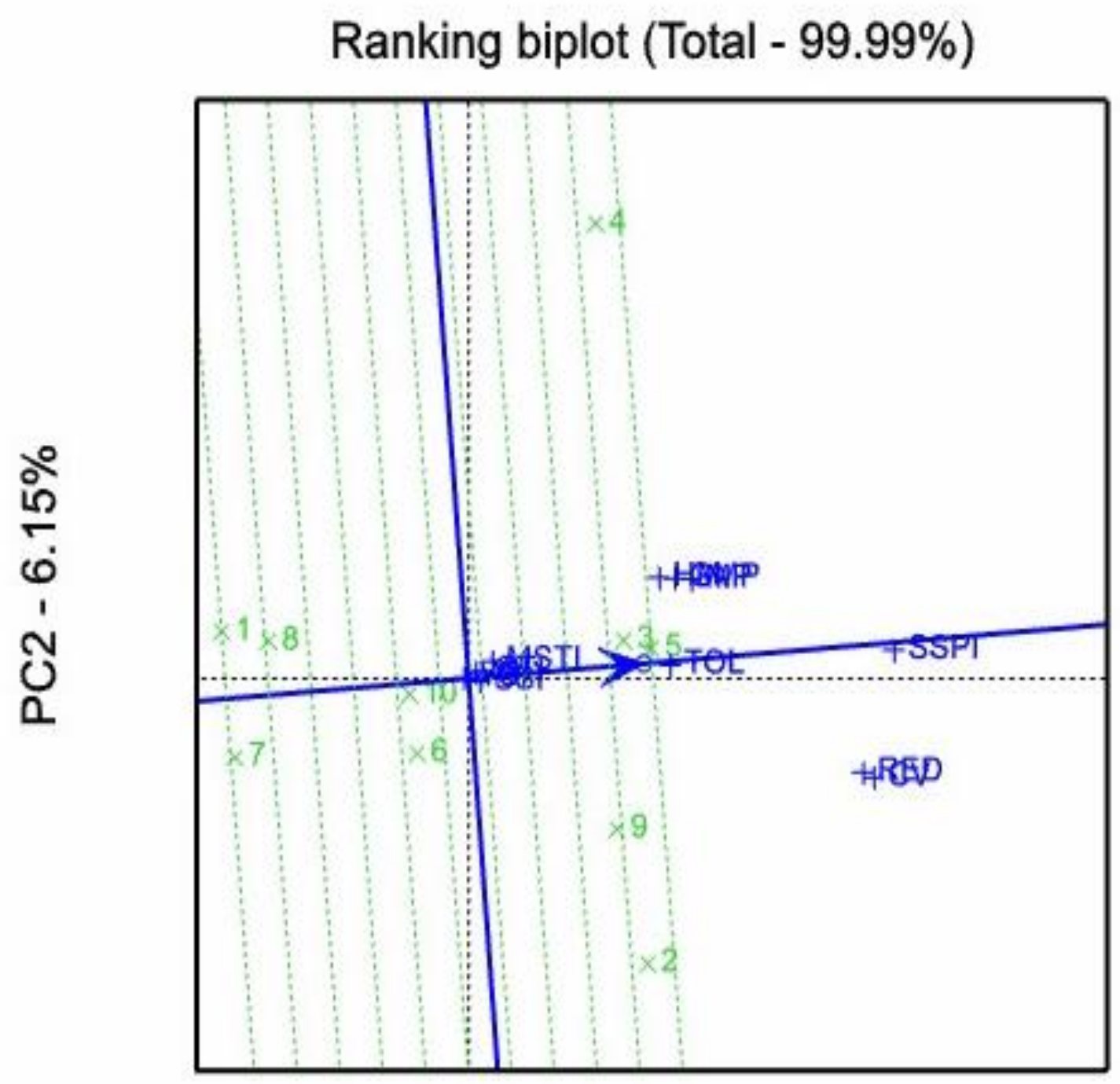

PC1 - $93.83 \%$

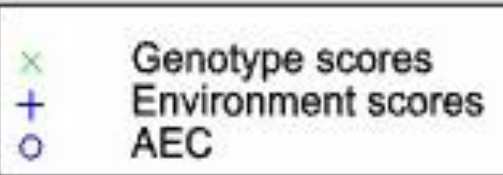

Fig. (1): Biplot graph of the first two principal component axes for12 salt tolerance

36.72 , respectively. They can be subjected to supplementary experiments so as to avoid omitting the good genotypes (Anagholi et al., 2018). The results of the calculated indices indicated that, the least Tol and Red index pertained to BTS 8115 and BTS 3980 which were found having a low mean production for its low yield under unstressed conditions, so it is not useful for salinity stress.
It is noted that indices of MP, HM, GMP, STI, YI and MSTI gave similar ranks for salt tolerance where the varieties Oscarpoly, Clavius and Athospoly verities were identified as salt tolerant varieties. The aforementioned varieties had greater scores of evidences; the higher values of these indices indicate that they are more tolerant varieties. While varieties BTS 8115, BTS 3980 and Palace were identified as sensitive, because of their low estimates of such 
indices. In the same context, the indices TOL and SSPI ranked the tested varieties for salt tolerance in the same order. Using these two indices, the varieties BTS 3980 and BTS 8115 were more tolerant for salinity, while Clavius and Panther verities were more sensitive compared to the others. A similar ranking pattern of tolerant/sensitive varieties was obtained by the indices Red, SSI and CV. Accordingly, BTS 3980 and BTS 8115 were preferred for cultivation in the salt site, while Panther and Pepite were more sensitive for salinity. The similarity among indices in ranking varieties for salt tolerance may be attributed to that these indices are a function of each other as shown in Table (7). However, the three indices YSI and MSTI gave a different arrangement of varieties for their tolerance to salinity. A similar trend was found by Asadi et al. (2012), AlAshkar and El-Kafafi (2014), Al Naggar et al. (2015), Singh et al. (2015) and Ali and El-Sadek (2016).

On the other hand, the yield indices, MP, HM, GMP, STI, YI and MSTI ranked the tested varieties for salt tolerance exactly like the average root yield under the stress condition, which means that these indices emphasized on information could be provided by root yield itself (Table 7).

\subsection{The relationships and overlap among salinity tolerance indices}

This part of the study aimed to explore the similarity/dissimilarity among the salinity tolerance indices that are closely related in ranking the tested sugar beet varieties. To achieve this goal, Spearman rank correlation coefficients (r) among salinity tolerance indices as well as mean root yield (under adequate and salt sites) were calculated and presented in Table (8). The rank correlation was used instead of Pearson coefficient of correlation because the salinity tolerance indices are estimated but not measured values, so, cannot be assumed to be normally distributed (Becker, 1981). When a perfect correlation coefficient $(\mathrm{r}=1)$ was obtained between two salinity tolerance indices, they would be considered identical indices. However, if the association between two salinity tolerance indices was very strong (highly significant but not perfect, $0.75 \leq \mathrm{r}<1.0$ ), these two indices would be as equivalent.

On the other hand, principal components (PC) analysis based on Spearman rank correlation matrix, was performed. For best visualization, the loading of the first two principal components were plotted against each other. The results are diagrammatically displayed as biplot graph of PC1 and PC2 in Fig. (1). It is noted that the first two PC's shared by $99.99 \%$ ( 93.83 and $6.15 \%$ by PC1 and PC2, respectively) of the variance structure, indicating that the biplot graph is characterized by a goodness of fit and successfully reflected the linear relationships among stress tolerance indices. The results showed that the yield under salt-stressed site (Ys) had a very strong association $(r=0.949)$ with the yield under optimal conditions (Yn), indicating that high potential yield under non-stressed conditions necessarily resulted in improved yield under the stressed salinity conditions and vice versa.

Based on the rank correlation matrix (Table 8), it is observed that Yn and Ys were positively and significantly associated with all salinity tolerance indices, except for YSI when the correlation was negative not only with Yn and Ys but also with the rest of the other indices. Because of the perfect association between (MP and GMP), (HM and STI), (TOL and SSP) and( Red and CV) as well $(\mathrm{r}=1)$ they occupied the same dot on the biplot graph. These results indicated that the average root yield under adequate and stress condition in an equal footing (Yn and $Y_{\mathrm{s}}$ ) are the effective parts in computing the most stress tolerance indices. Graphically, GMP already was located close to HM and STI with an acute angle (positive correlation).

Concerning the relationships among stress tolerance indices, the results appeared that there were highly significant and positive associations between each pair of the indices MP, HM, GMP, STI, YI, YSI and MSTI, but the last two indices took the opposite trend for each other (obtuse angles). Therefore, their dots were closely located on the biplot graph with acute angles.

\section{Conclusion}

It can be inferred according to the present results that there has been a positive benefit in introducing the salt tolerant varieties and they have been accompanied by useful components. Amongst the genotypes that possessed high root yield on average, the Oscarpoly variety can be selected. This variety featured high values of mean productivity (MP), harmonic mean (HM), geometric mean productivity (GMP), stress tolerance index (STI), yield index(YI), yield stability index (YSI), and modified stress tolerance index (MSTI) followed by Athospoly and Clavius. Oscarpoly, Clavius and Athospoly 
Table(7): Mean of Salt Tolerance Indices (STI) and their respective ranks of 10 sugar beet varieties based on average of root yield under

\begin{tabular}{|c|c|c|c|c|c|c|c|c|c|c|c|c|c|c|}
\hline \multirow{3}{*}{$\begin{array}{c}\text { Sugar beet } \\
\text { Varieties }\end{array}$} & \multirow{2}{*}{\multicolumn{2}{|c|}{ Root yield/fed (ton). }} & \multirow{2}{*}{\multicolumn{12}{|c|}{ adequate and salt sites of the two seaso }} \\
\hline & & & & & & & & & & & & & & \\
\hline & $\mathbf{Y}_{\mathbf{n}}$ & $\mathbf{Y}_{\mathrm{s}}$ & $\mathbf{M P}^{1}$ & $\mathrm{H} \mathrm{M}^{\mathbf{1}}$ & GMP $^{1}$ & STI $^{1}$ & $\mathbf{Y I}^{1}$ & TOL $^{2}$ & SSPI $^{2}$ & YSI $^{1}$ & MSTI $^{1}$ & Red $^{2}$ & SSI $^{2}$ & $\mathbf{C V}^{2}$ \\
\hline \multicolumn{15}{|c|}{ Calculated values } \\
\hline 1.BTS-3980 & 21.14 & 14.63 & 17.89 & 17.29 & 17.59 & 0.55 & 0.941 & 6.51 & 13.72 & 0.692 & 0.49 & 30.79 & 0.894 & 25.74 \\
\hline 2.Panther & 24.80 & 15.50 & 20.15 & 19.08 & 19.61 & 0.68 & 0.997 & 9.3 & 19.60 & 0.625 & 0.68 & 37.50 & 1.088 & 32.64 \\
\hline 3.Athospoly & 25.56 & 16.29 & 20.93 & 19.90 & 20.41 & 0.74 & 1.048 & 9.27 & 19.53 & 0.637 & 0.81 & 36.27 & 1.052 & 31.33 \\
\hline 4.Oscarpoly & 26.58 & 17.35 & 21.97 & 21.00 & 21.47 & 0.82 & 1.116 & 9.23 & 19.45 & 0.653 & 1.02 & 34.73 & 1.008 & 29.71 \\
\hline 5.Clavius & 25.84 & 16.37 & 21.11 & 20.04 & 20.57 & 0.75 & 1.053 & 9.47 & 19.96 & 0.634 & 0.83 & 36.65 & 1.063 & 31.73 \\
\hline 6.Pinta & 22.92 & 15.16 & 19.04 & 18.25 & 18.64 & 0.62 & 0.975 & 7.76 & 16.35 & 0.661 & 0.59 & 33.86 & 0.982 & 28.82 \\
\hline 7.BTS-8115 & 20.89 & 14.34 & 17.62 & 17.01 & 17.31 & 0.53 & 0.922 & 6.55 & 13.80 & 0.686 & 0.45 & 31.35 & 0.910 & 26.29 \\
\hline 8.Palace & 21.63 & 14.82 & 18.23 & 17.59 & 17.90 & 0.57 & 0.953 & 6.81 & 14.35 & 0.685 & 0.52 & 31.48 & 0.914 & 26.42 \\
\hline 9.Pepite & 24.89 & 15.75 & 20.32 & 19.29 & 19.80 & 0.70 & 1.013 & 9.14 & 19.26 & 0.633 & 0.71 & 36.72 & 1.066 & 31.81 \\
\hline 10.Carrot & 23.02 & 15.29 & 19.16 & 18.38 & 18.76 & 0.63 & 0.983 & 7.73 & 16.29 & 0.664 & 0.60 & 33.58 & 0.974 & 28.54 \\
\hline \multicolumn{15}{|c|}{ Corresponding ranks } \\
\hline 1.BTS-3980 & 9 & 9 & 9 & 9 & 9 & 9 & 9 & 10 & 10 & 1 & 9 & 10 & 10 & 10 \\
\hline 2.Panther & 5 & 5 & 5 & 5 & 5 & 5 & 5 & 2 & 2 & 10 & 5 & 1 & 1 & 1 \\
\hline 3.Athospoly & 3 & 3 & 3 & 3 & 3 & 3 & 3 & 3 & 3 & 7 & 3 & 4 & 4 & 4 \\
\hline 4.Oscarpoly & 1 & 1 & 1 & 1 & 1 & 1 & 1 & 4 & 4 & 6 & 1 & 5 & 5 & 5 \\
\hline 5.Clavius & 2 & 2 & 2 & 2 & 2 & 2 & 2 & 1 & 1 & 8 & 2 & 3 & 3 & 3 \\
\hline 6.Pinta & 7 & 7 & 7 & 7 & 7 & 7 & 7 & 6 & 6 & 5 & 7 & 6 & 6 & 6 \\
\hline 7.BTS-8115 & 10 & 10 & 10 & 10 & 10 & 10 & 10 & 9 & 9 & 2 & 10 & 9 & 9 & 9 \\
\hline 8.Palace & 8 & 8 & 8 & 8 & 8 & 8 & 8 & 8 & 8 & 3 & 8 & 8 & 8 & 8 \\
\hline 9.Pepite & 4 & 4 & 4 & 4 & 4 & 4 & 4 & 5 & 5 & 9 & 4 & 2 & 2 & 2 \\
\hline 10.Carrot & 6 & 6 & 6 & 6 & 6 & 6 & 6 & 7 & 7 & 4 & 6 & 7 & 7 & 7 \\
\hline
\end{tabular}

1 The highest value of this index indicates to the more tolerant variety.

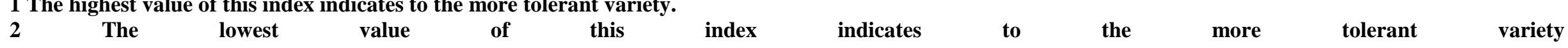


Table (8): Spearman rank correlation coefficients among root yield (under adequate and salt stress), and their corresponding salt tolerance indices.

\begin{tabular}{|c|c|c|c|c|c|c|c|c|c|c|c|c|c|c|}
\hline $\begin{array}{l}\text { Indi } \\
\text { ces }\end{array}$ & $Y_{n}$ & $\mathrm{Y}_{\mathrm{s}}$ & MP & $\mathrm{H} \mathrm{M}$ & $\begin{array}{l}\text { GM } \\
\mathrm{P} \\
\end{array}$ & STI & YI & TOL & SSPI & YSI & $\begin{array}{l}\text { MS } \\
\text { TI } \\
\end{array}$ & $\begin{array}{l}\mathrm{RE} \\
\mathrm{D} \\
\end{array}$ & $\begin{array}{l}\text { SSP } \\
\text { I } \\
\end{array}$ & $\mathrm{CV}$ \\
\hline$Y_{n}$ & 1 & & & & & & & & & & & & & \\
\hline $\mathrm{Y}_{\mathrm{s}}$ & $\begin{array}{l}0.94 \\
9^{* * *}\end{array}$ & 1 & & & & & & & & & & & & \\
\hline MP & $\begin{array}{l}0.99 \\
5^{* * *}\end{array}$ & $\begin{array}{l}0.97 \\
5^{* *}\end{array}$ & 1 & & & & & & & & & & & \\
\hline $\begin{array}{l}\mathrm{H} \\
\mathrm{M}\end{array}$ & $\begin{array}{l}0.98 \\
6^{* *}\end{array}$ & $\begin{array}{l}0.98 \\
8^{* * *}\end{array}$ & $\begin{array}{l}0.99 \\
8^{* *}\end{array}$ & 1 & & & & & & & & & & \\
\hline $\begin{array}{l}\text { GM } \\
\text { P }\end{array}$ & $\begin{array}{l}0.99 \\
2^{* * *}\end{array}$ & $\begin{array}{l}0.98 \\
1^{* * *}\end{array}$ & $\begin{array}{l}1.00 \\
0\end{array}$ & $\begin{array}{l}0.99 \\
9^{* * *}\end{array}$ & 1 & & & & & & & & & \\
\hline STI & $\begin{array}{l}0.98 \\
7^{* * *}\end{array}$ & $\begin{array}{l}0.98 \\
6^{* * *}\end{array}$ & $\begin{array}{l}0.99 \\
8^{* * *}\end{array}$ & $\begin{array}{l}1.00 \\
0\end{array}$ & $\begin{array}{l}0.99 \\
9^{* *}\end{array}$ & 1 & & & & & & & & \\
\hline YI & $\begin{array}{l}0.94 \\
8^{* * *}\end{array}$ & $\begin{array}{l}0.99 \\
9^{* * *}\end{array}$ & $\begin{array}{l}0.97 \\
4^{* *}\end{array}$ & $\begin{array}{l}0.98 \\
7^{* * *}\end{array}$ & $\begin{array}{l}0.98 \\
0_{* * *}^{* * 3}\end{array}$ & $\begin{array}{l}0.988 \\
5^{* * *}\end{array}$ & 1 & & & & & & & \\
\hline $\begin{array}{l}\text { TO } \\
\text { L }\end{array}$ & $\begin{array}{l}0.97 \\
2^{* * *}\end{array}$ & $\begin{array}{l}0.84 \\
8^{* * *}\end{array}$ & $\begin{array}{l}0.94 \\
4^{* *}\end{array}$ & $\begin{array}{l}0.92 \\
1^{* * *}\end{array}$ & $\begin{array}{l}0.93 \\
4^{* * *}\end{array}$ & $\begin{array}{l}0.92 \\
3^{* * *}\end{array}$ & $\begin{array}{l}0.84 \\
8^{* * *}\end{array}$ & 1 & & & & & & \\
\hline SSP & $\begin{array}{l}0.97 \\
2^{* * *}\end{array}$ & $\begin{array}{l}0.84 \\
8^{* * *}\end{array}$ & $\begin{array}{l}0.94 \\
4^{* *}\end{array}$ & $\begin{array}{l}0.92 \\
1^{* * *}\end{array}$ & $\begin{array}{l}0.93 \\
4^{* * *}\end{array}$ & $\begin{array}{l}0.92 \\
3^{* * *}\end{array}$ & $\begin{array}{l}0.84 \\
8^{* * *}\end{array}$ & $\begin{array}{l}1.00 \\
0\end{array}$ & 1 & & & & & \\
\hline YSI & $\begin{array}{l}- \\
0.88 \\
8^{* * *}\end{array}$ & $\begin{array}{l}- \\
0.70 \\
4^{* *}\end{array}$ & $\begin{array}{l}- \\
0.84 \\
0^{* *}\end{array}$ & $\begin{array}{l}- \\
0.80 \\
5^{* * *}\end{array}$ & $\begin{array}{l}- \\
0.82 \\
5^{* *}\end{array}$ & $\begin{array}{l}- \\
0.80 \\
9^{* * *}\end{array}$ & $\begin{array}{l}- \\
0.70 \\
0^{* * *}\end{array}$ & $\begin{array}{l}- \\
0.96 \\
5^{* * *}\end{array}$ & $\begin{array}{l}- \\
0.96 \\
5^{* *}\end{array}$ & 1 & & & & \\
\hline $\begin{array}{l}\text { MS } \\
\text { TI }\end{array}$ & $\begin{array}{l}0.95 \\
5^{* * *}\end{array}$ & $\begin{array}{l}0.99 \\
8^{* *}\end{array}$ & $\begin{array}{l}0.97 \\
9^{* * *}\end{array}$ & $\begin{array}{l}0.99 \\
0 * * *\end{array}$ & $\begin{array}{l}0.98 \\
4^{* * *}\end{array}$ & $\begin{array}{l}0.98 \\
9^{* * *}\end{array}$ & $\begin{array}{l}0.99 \\
9^{* * *}\end{array}$ & $\begin{array}{l}0.86 \\
1^{* * *}\end{array}$ & $\begin{array}{l}0.86 \\
1^{* * *}\end{array}$ & $\begin{array}{l}0.71 \\
6^{* *}\end{array}$ & 1 & & & \\
\hline $\begin{array}{l}\mathrm{RE} \\
\mathrm{D}\end{array}$ & $\begin{array}{l}0.86 \\
9^{* * *}\end{array}$ & $\begin{array}{l}0.66 \\
9^{* * *}\end{array}$ & $\begin{array}{l}0.81 \\
6^{* *}\end{array}$ & $\begin{array}{l}0.77 \\
7^{* *}\end{array}$ & $\begin{array}{l}0.79 \\
9^{* *}\end{array}$ & $\begin{array}{l}0.78 \\
1^{* * *}\end{array}$ & $\begin{array}{l}0.66 \\
8^{* * *}\end{array}$ & $\begin{array}{l}0.96 \\
0^{* * *}\end{array}$ & $\begin{array}{l}0.96 \\
0^{* * *}\end{array}$ & $\begin{array}{l}- \\
0.99 \\
0^{* * *}\end{array}$ & $\begin{array}{l}0.68 \\
6^{* *}\end{array}$ & 1 & & \\
\hline $\begin{array}{l}\text { SSP } \\
\text { I }\end{array}$ & $\begin{array}{l}0.86 \\
9^{* * *}\end{array}$ & $\begin{array}{l}0.66 \\
9^{* * *}\end{array}$ & $\begin{array}{l}0.81 \\
6^{* *}\end{array}$ & $\begin{array}{l}0.77 \\
7^{* * *}\end{array}$ & $\begin{array}{l}0.79 \\
9^{* * *}\end{array}$ & $\begin{array}{l}0.78 \\
1^{* * *}\end{array}$ & $\begin{array}{l}0.66 \\
8^{* * *}\end{array}$ & $\begin{array}{l}0.96 \\
0^{* * *}\end{array}$ & $\begin{array}{l}0.96 \\
0^{* * *}\end{array}$ & $\begin{array}{l}- \\
0.98 \\
8^{* *}\end{array}$ & $\begin{array}{l}0.68 \\
7^{* * *}\end{array}$ & $\begin{array}{l}0.99 \\
9^{* * *}\end{array}$ & 1 & \\
\hline $\mathrm{CV}$ & $\begin{array}{l}0.86 \\
6^{* * *}\end{array}$ & $\begin{array}{l}0.66 \\
4^{* * *}\end{array}$ & $\begin{array}{l}0.81 \\
3^{* *}\end{array}$ & $\begin{array}{l}0.77 \\
3^{* *}\end{array}$ & $\begin{array}{l}0.79 \\
5^{* *}\end{array}$ & $\begin{array}{l}0.77 \\
7^{* * *}\end{array}$ & $\begin{array}{l}0.66 \\
3^{* *}\end{array}$ & $\begin{array}{l}0.95 \\
9^{* * *}\end{array}$ & $\begin{array}{l}0.95 \\
9^{* * *}\end{array}$ & $\begin{array}{l}- \\
0.98 \\
9^{* * *}\end{array}$ & $\begin{array}{l}0.68 \\
1^{* * *}\end{array}$ & $\begin{array}{l}1.00 \\
0\end{array}$ & $\begin{array}{l}0.99 \\
9^{* *}\end{array}$ & 1 \\
\hline
\end{tabular}

** indicate significant at 0.01 probability level. 
varieties had higher root yield and better stress tolerance indices than others, therefore can be candidate as the best selectable varieties for salinity tolerance. Varieties Panther and Pepite can be classified as acceptable ones due to their higher Tol and reduction index. Carrot, Pintea and Palace had lower differences in stress and unstressed conditions but lower STI and low mean productivity together.

\section{REFERENCES}

Abbasi Z., Majidi M.M., Arzani A., Ragabi A., Akbar J.M.R. and Mashayekhi P. (2013). Identification of $\mathrm{S} 1$ families as diploid pollinators for the development of salt tolerante hybrid in sugar beet. Appl. Crop Breed. J., 1(2):59-72.

Al-Ashkar I.M. and El-Kafafi S.H. (2014). Identification of traits contributing salt tolerance in some doubled haploid wheat lines at seedling stage. Middle East J. Appl. Sci., 4(4): 1130-1140.

Ali M.B. and El-Sadek A.N. (2016). Evaluation of drought tolerance indices for wheat (Triticum aestivum L.) under irrigated and rainfed conditions. Communications in Biometry and Crop Sci., 11(1): 77-89.

Al-Naggar A.M.M., Sabry S.R.S., Atta M.M.M. and Abd El-Aleem M. O. (2015). Effects of salinity on performance, heritability, selection gain and correlations in wheat (Triticum aestivum L.) Doubled Haploids. Sci. Agric., 10(2): 70-83.

Aly E.F.A., Abdel Fatah E. M. and Khalil S. R. A. (2014). Response of some sugar beet varieties to the integrated soil and foliar application of potassium. Fayoum J. Agric. Res. \& Dev., 28(2): 155-172.

Anagholi A., Rajabi A. and Khayamim S. (2018). Screening salt-tolerant sugar beet genotypes using stress tolerance indices. Pharmacophore, 9(2): 60-71.

Armioum M. (2002). Evaluation of some biochemical markers in salinity tolerance of wild and agronomic sugar beet. M.Sc. Thesis. Agric. College. Shiraz University, Iran.

Asadi M., Nejad G. M., P.Golkar., Naghavi. H. and Nakhoda B. (2012). Assessment of salinity tolerance of different promising lines of bread wheat (Triticum aestivum L.). Adv. In Appl. Sci. Res., 3(2): 1117-1121.

Babazade H., Tabrizi S. M. and Darvish. H.H. (2016). Adapting adequate leaching requirement for practical response models of basil to salinity. Int. Agrophys, 30: 2-10.

Bates L.S., Waldren R.P. and Teare I.D. (1973). Rapid determination of free proline for water-stress studies. Plant Soil, 39: 205207.

Becker H.C. (1981). Correlations among statistical measures of phenotypic stability. Euphytica, 30: 835-840.

Bouslama M. and Schapaugh W.T. (1984). Stress tolerance in soybean, evaluation of three screening techniques for heat and drought tolerance. Crop Sci., 24: 933-937.

Brown J.D. and Lilliand O. (1964). Rapid determination of potassium and sodium in plant material and soil in extracts by Flame photometry. Pro. Amer. Soc. Hort. Sci. (48): 341-346.

Brown K.F., Gowan M. M. and Armstrong. M.J. (1987). Response of the components of sugar beet leaf water potential to drying soil profile. J. Agric. Sci. Camb., 109: 437-444.

Carruthers A., Oldfield J.F.T. and Teague H.J. (1962). Assessment of beet quality. Paper presented to the $15^{\text {th }}$ Annual Technical Conference, British Sugar Corporation, 36. (C.F. The sugar Beet crop Book, 552-553, $1^{\text {st }}$ Edition published by Chapman and Hall, Univ. Press, Cambridge, UK.).

Cooke D.A. and Scott R.K. (1993). The Sugar Beet Crop. Science Practice. Published by Chapman and Hall, London. P., 595-605.

Dadkhah. A.R. (2005). Response of root yield and quality of sugar beet (Beta vulgaris) to salt stress. Iran Agricultural. Res., 23(2): 34-41.

Darwish M.A.H., Fares W.M. and Eman M.A. Hussein (2017). Differentiating some bread wheat genotypes using salinity tolerance indices and multivariate analysis.

Dexter S.T., Frankes M.G. and Snyder F.W. (1967). A rapid method of determination extractable white sugar as may be applied to the evaluation of agronomic practices and grower deliveries in the sugar beet industry. J. Am., Soc., Sugar beet Technol. (14): 433-454.

Farshadfar E. Andsutka J. (2002). Screening drought tolerance criteria in maize. Acta Agron. Hung., 50(4): 411-416.

Fernandez G.C.J. (1992). Effective selection criteria for assessing plant stress tolerance. Proceeding of the International Symposium on Adaptation of Vegetables and other 
Food Crops in Temperature and Water Stress. Taiwan, pp.257-270.

Fischer R. A. and Maurer R. (1978). Drought resistance in spring wheat cultivars. Aust. J. Agric. Res., 29: 897-912.

Gavuzzi P., Rizza. F., Palumbo M., Campaline. R.G., Ricciardi. G.L. and Borghi. B. (1997). Evaluation of field and laboratory predictors of drought and heat tolerance in winter cereals. Canadian J. Plant Sci., 77: 523-531.

Grieve C.M. and Grattan S.R. (1983). Rapid assay for determination of water soluble quaternary ammonium compounds. Plant Soil, 70: 303-307.

Hanin M., Ebel C., Ngom. M., Laplaze L. and Masmoudi K. (2016). New insights on plant salt tolerance mechanisms and their potential use for breeding. Front. Plant Sci., 7: 1787-1803.

Hoffmann C.M., Huijbregts T., Van Swaaij N. and Jansen R. (2009). Impact of different environments in Europe on yield and quality of sugar beet genotypes. Euro. J. Agron., 30: 17-26

Jafari A., Paknejad F. and Al-Ahmaidi M. (2009). Evaluation of selection indices for drought tolerance of corn (Zea mays L.) hybrids. Int. J. Plant Prod., 3: 33-38.

Khafagi O. A. and El-Lawendy A. M. (1996). Salt tolerance of sugar beet (Beta vulgaris L.), metabolic products and ion accumulation. Ann. Agric. Sci. Moshtohor, 34:1647-1661.

Le-Docte A. (1927). Commercial determination of sugar in the beet root using the sacks, Le-Docte process. Int.`1 Sug. J. (29), 488492.

Leven H. (1960). Robust tests for equality of variances. In Ingram Olkin, Harold Hotel ling, Italia, Stanford, Univ. Press,USA, 278-292.
Mass E.V. and Grattan S.R. (1999). Crop yield as affected by salinity. Agric. Drain. Agro. Monograph., 38: 55-107.

Moosavi S.S., Samadi B.Y., Naghavi M.R., Zali A.A., Dasht $\mathrm{H}$ and Pourshahbazi A. (2008). Introduction of new indices to identify relative drought tolerance and resistance in wheat genotypes. Desert, 12: 165-178.

Nasab A., Hasibi N., Roshan P., Fekr H. and Bashi M. (2011). Evaluation of some physiology response of sugar beet cultivars under salinity stress. $1^{\text {st }}$ expertly conference about opportunity methods for sustainable agriculture. Khozestan Payam Nour University. Ahvaz, Iran.

Ranjbar G. and Anagholi A. (2018). Concepts of salt stress and plant response. Agric. Educ. And Extension Press., Tehran, Iran.

Rosielle A.A. and Hamblin J. (1981). Theoretical aspect of selection for yield in stress and non-stress environment. Crop. Sci., 21: 943-946.

Ruiz-Holst M., Martin F.D., Burba M., Elias P. D. and Diener G. (2003). Assessment of the technical quality of sugar beet in Southern Spain. Zuckerindustrie, 128: 879887.

Singh S., Senger R.S. and Kulshreshta N. (2015). Differential response of selected bread wheat (Triticum aestivum L.) genotypes for salt tolerance by using multiple parameters. J. wheat Res., 8(1): 19-24.

Steel R.G.D., Torrie J.H. and Dickey D.A. (1977). Principles and Procedures of Statistics. A Biometrical Approach. $3^{\text {rd }}$ ed. Mc Graw Hill Book Co. New York, USA.

Yan W. and Rajcan I. (2002). Biplot analysis of test sites and trait relations of soybean in Ontario. Crop Sci., (42): 11-20. 


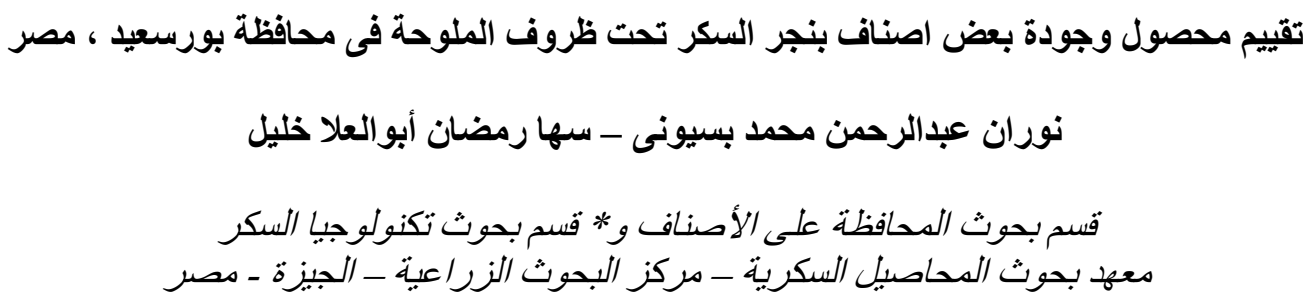

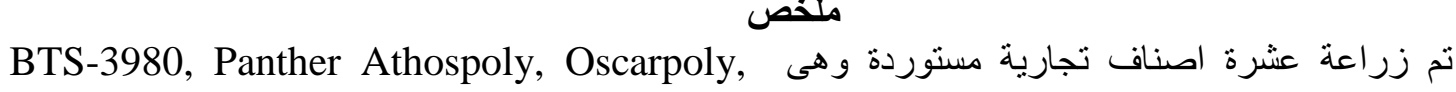
Clavius, Pintea, BTS-8115, Palace, pepite , Carrot

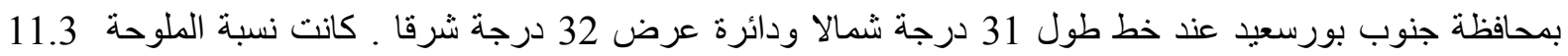

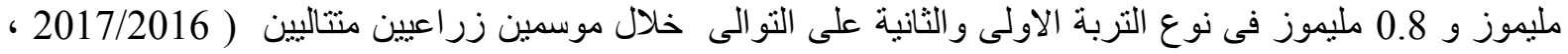

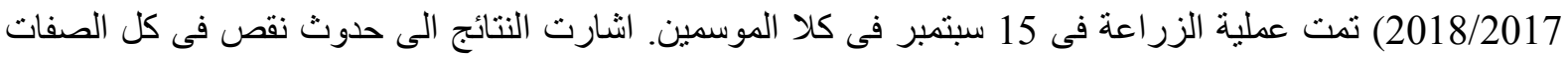

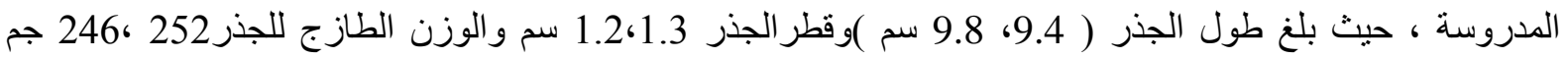

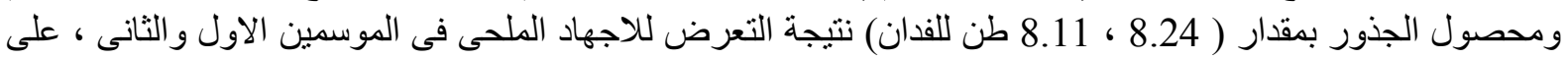

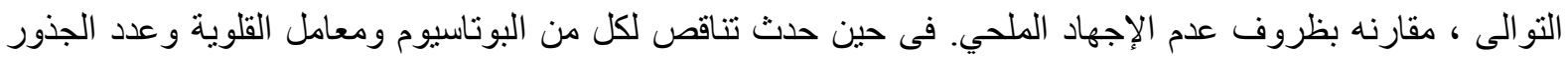

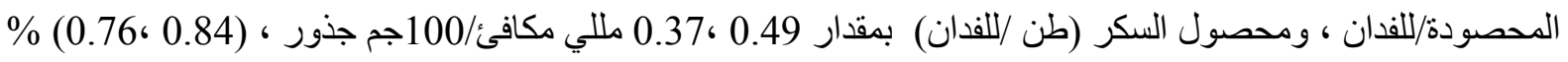

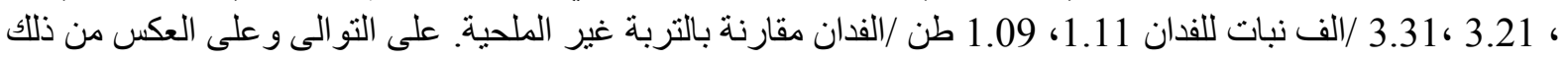

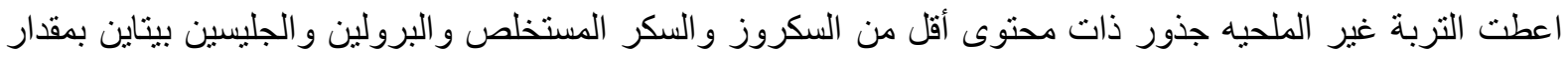

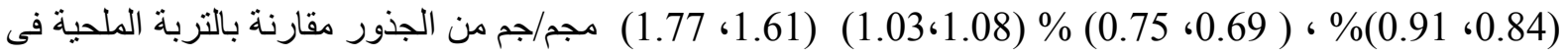

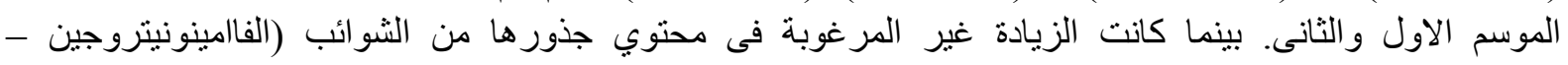

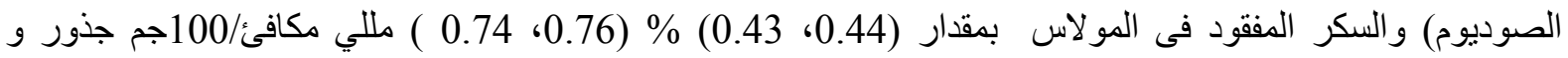

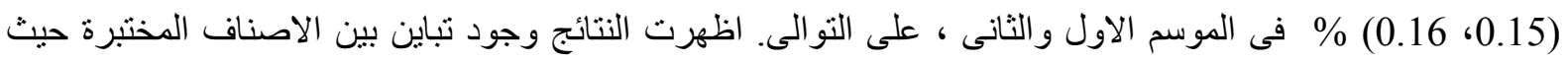

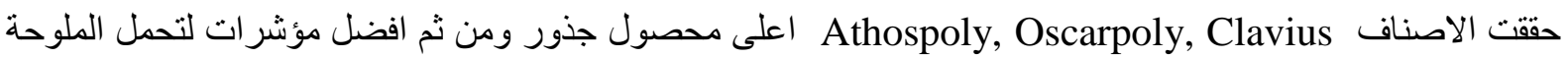
و وبالتالى يمكن اعتبار ها كأكثر الاصناف المختبره تحملا للملوحها. وفى نفس الوقت اعطى اعلى كلا من الصنفين

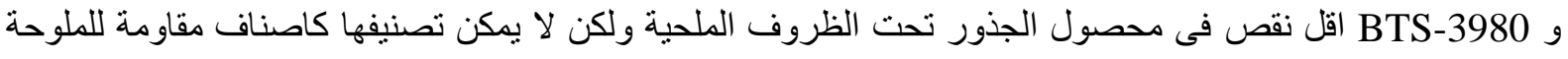

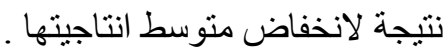

